\title{
Standing on the shoulders of giants: 100 years of neurology and epidemic infections
}

\author{
Harriett Van Den Tooren, ${ }^{1,2}$ Mark A Ellul, ${ }^{1,3,4}$ Nicholas WS Davies, ${ }^{5}$ Ava Easton, ${ }^{4,6}$ Angela Vincent, ${ }^{7,8}$ \\ Tom Solomon, 1,3,4 Benedict Daniel Michael (D) ,1,3,4 On behalf of the CoroNerve Studies Group
}

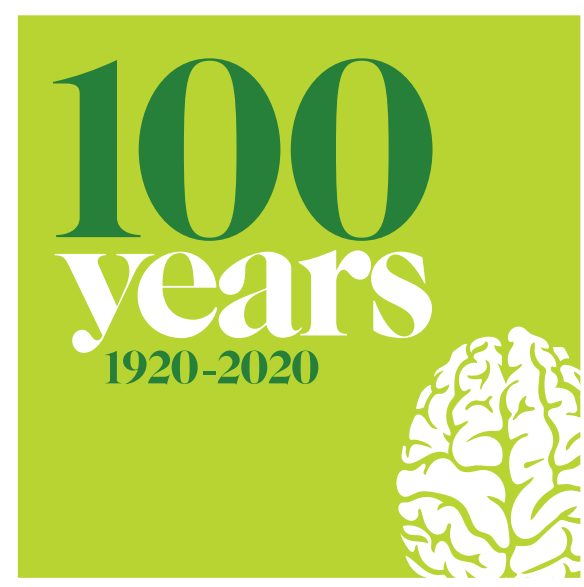

Introduction

One hundred years ago, neurologists were faced with a surge of cases of uncertain cause manifesting a protean array of symptoms. Through careful semiological description, pattern recognition and histopathological analysis, von Economo and others unified these seemingly disparate cases, defining the epidemic of encephalitis lethargica. Several landmark papers in the Journal of Neurology and Psychopathology (now JNNP) helped to illuminate clinical and pathological aspects of this new disease. In the subsequent hundred years, there have been other infectious epidemics affecting the nervous system, with causative agents including flaviviruses, influenza, enteroviruses (eg, poliomyelitis) and coronaviruses (CoV).

${ }^{1}$ Neurology, The Walton Centre NHS Foundation Trust, Liverpool, UK

${ }_{2}^{2}$ Medicine, Hull University Teaching Hospital, Hull, UK ${ }^{3} \mathrm{NIHR}$ HPRU for Emerging and Zoonotic Infection, Liverpool, UK

${ }^{4}$ Clinical Infection Microbiology and Immunology, Institute of Infection, Veterinary and Ecological Sciences, Liverpool, UK

${ }^{5}$ Neurology, Chelsea and Westminster Hospital, London, UK

${ }^{6}$ Encephalitis Society, Malton, UK

${ }^{7}$ Neurosciences Group, Weatherall Institute of Molecular Medicine, University of Oxford, John Raddliffe Hospital, Oxford, UK

${ }^{8}$ Institute of Neuroscience, University College London, London, UK

Correspondence to Dr Benedict Daniel Michael, NIHR HPRU for Emerging and Zoonotic Infection, Liverpool, UK; benmic@liv.ac.uk
A case of encephalitis lethargica

involving chiefly the cerebral cortex

Authors: Watson GA

Year Published: 1920

Epidemic encephalitis: Clinical papers by

various authors

Authors: Horder T

Year Published: 1920

Neurologists seeing patients in the age of COVID-19 have much to gain from the historical lessons of the epidemics of the last 100 years in responding to these new challenges.

\section{ENCEPHALITIS LETHARGICA}

The first systematic descriptions of encephalitis lethargica were those of von Economo in 1916-1917, who coined the term (figure 1), ${ }^{1}$ which is also known as

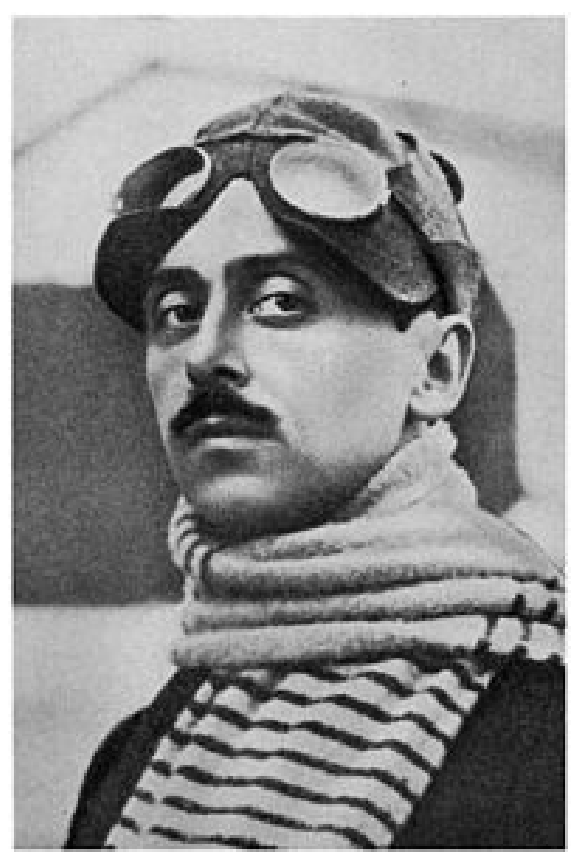

Figure 1 Constantin Freiherr Economo von San Serff (von Economo (1876-1931)) Austrian neurologist, psychiatrist, pilot and originator of the diagnosis encephalitis lethargica (https://commons.wikimedia.org/wiki/ Category:Constantin_von_Economo). 'von Economo's disease'. ${ }^{2}$ However, there were probable cases in 1915 predating the 'influenza epidemic', and von Economo and others suggested that earlier epidemics throughout modern history may also have been related. ${ }^{3}$

Encephalitis lethargica appears to have spread from Eastern Europe to Germany, France and Britain between 1916 and 1918 and and then to have affected much of the rest of the world in the following few years. ${ }^{14}$ It probably affected more than a million people during the first half of the twentieth century, before apparently disappearing, although some clinicians have continued to apply the diagnosis, particularly in children. ${ }^{4}$ Three forms were recognised by von Economo: 'somnolent-ophthalmoplegic form' characterised by mild prodrome and somnolence with ophthalmoplegia; 'hyperkinetic form' in which the patients had sudden onset neck and back pain followed by mental and motor unrest; a 'myostaticakinetic form' that had a milder acute phase of weakness and rigidity and was more likely to have chronic sequelae which could occur immediately after the acute phase or after months or years. ${ }^{14}$ Most patients had change in conscious level, and von Economo discriminated carefully between somnolence as a result of brain dysfunction versus that caused by systemic disease $^{2}-\mathrm{a}$ distinction which clearly remains important for COVID-19.

Histopathology of most cases in the acute phase showed reddish-grey discolouration of the brainstem grey matter with lymphocytic infiltrates surrounding vessels and diffuse inflammation with haemorrhage. ${ }^{1}$ In the chronic phase, persistent inflammation was evident with generalised brain atrophy and degeneration of the substantia nigra. ${ }^{1}$

The aetiology remains unproven, and it is not clear whether all the cases in the literature truly represent a single disease. ${ }^{5}$ The prevailing contemporary hypothesis was that proposed by von Economo himselfthat the disease was owing to an infectious agent, although he observed that cases appeared to predate the emergence of the 
1918 influenza pandemic. ${ }^{25}$ von Economo's view that the disease was the result of direct viral infection of the central nervous system (CNS) has now been largely superseded by the proposition that the disease reflected a para/post-infectious inflammatory process. ${ }^{5}$ Although evidence for this is lacking, it fits neatly with the modern view of other neurological syndromes such as Guillain-Barré syndrome (GBS), acute disseminated encephalomyelitis (ADEM) and N-methyl-D-aspartate receptor (NMDA-R) antibody encephalitis, the latter of which may be triggered by herpes simplex virus in some. ${ }^{67}$ Indeed, NMDA-R antibodies were present in serum (and cerebrospinal fluid (CSF) when available for study) in around 50\% of 20 children with dyskinetic 'encephalitis lethargica' (collected over many years), ${ }^{8}$ and antibodies to the dopamine receptor in a proportion of the remaining more akinetic cases. Many of the clinical features overlap, although encephalitis lethargica is more heterogeneous in both its acute symptoms and its natural history. $^{2}$ A para/postinfectious pathogenesis, rather than direct viral infection, is in keeping with the observations that single members of families were often affected, which puzzled epidemiologists at the time; and that an infectious agent was not readily detected in CSF or brain tissue. ${ }^{2}$ It is possible that encephalitis lethargica represented a final common pathway of brain inflammation potentially triggered by several different infectious agents, although were this the case the reasons for the disease's decline remain obscure. Clinical material from patients with encephalitis lethargica is no longer available in sufficient quantity to support or refute the myriad aetiological hypotheses proposed over the last 100 years. $^{5}$

\section{ENCEPHALITIS LETHARGICA IN JNNP}

The British epidemic began in earnest in 1918 , and was a major burden on neurological, psychiatric and public health services for much of the first half of the twentieth century. ${ }^{9}$ Cases published in the Journal of Neurology and Psychopathology provide a glimpse of the struggles of neurologists trying to understand the emergence of this new enigma. ${ }^{1011}$ In 1920 , the journal published a case described by Watson, of the Rainhill asylum near Liverpool, then one of the largest asylums in Europe. ${ }^{10}$ While the condition was often thought to affect the brainstem, this case mainly affected the cerebral cortex. A young patient had been admitted in April 1918 with self-inflicted laceration across the neck, preceded by headache and sleeplessness for 2 weeks. ${ }^{10}$ Six months after the initial presentation, they developed neck and back pain with reduced mobility, 2 months later developing expressive aphasia with retained comprehension, and death occurred less than a month later. ${ }^{10}$ The postmortem results describe a widespread meningoencephalomyelitis with vascular proliferation, perivascular inflammation, thrombosis, haemorrhage and destruction of nervous tissue. ${ }^{10}$ A subsequent case series collated by Sir Thomas Horder, also published in 1920, comprises 25 cases described by several neurologists from Bristol, and is notable for detailed and varied descriptions of cases of encephalitis lethargica in patients of all ages. ${ }^{11}$ Their dilemmas trying to unify these disparate clinical presentations are clearly evident. While lethargy and/or psychiatric features are almost universal, movement disorders were variably present, as were corticospinal tract and cerebellar signs. ${ }^{11}$ The outcomes were varied with death in $10 / 25(40 \%)$ and residual neurological or psychiatric symptoms in most survivors. ${ }^{11}$ Speculation on aetiology in this study is limited, but there is an assumption that an infectious agent is responsible. Horder states that "it therefore becomes a matter of prime importance that clinicians should marshal their experiences, and set down their observations, with as much care and exactness as possible, and this whilst questions of exact pathology await the results of laboratory research". ${ }^{11}$

In subsequent years, papers in the journal analysed the phenomenology of sleep disorders in encephalitis lethargica, ${ }^{12}$ behavioural abnormalities in children ${ }^{13}$ and a case series of postencephalitic Parkinsonism ${ }^{14}$ among many others. Subsequently, fascinating reports emerged of the efforts to treat patients suffering with postencephalitic Parkinsonism with levodopa. ${ }^{15}$

\section{OTHER RESPIRATORY EPIDEMICS AFFECTING THE NERVOUS SYSTEM} Influenza

Although 1918 influenza has been suggested as the causative agent of encephalitis lethargica, similar clinical phenotypes have not been seen in association with other pandemic strains of influenza. ${ }^{5}$ However, a wide range of other neurological manifestations are described. The 2009 H1N1 pandemic was associated with complications of the nervous system in up to $4 \%$ of those diagnosed with H1N1 influenza infection and most commonly included altered mental status, seizures, narcolepsy and encephalopathy, particularly in children. ${ }^{16-18}$ Several seemingly pathognomic encephalopathy syndromes have emerged, including acute necrotising encephalopathy with bilateral thalamic involvement. ${ }^{16-18}$ The virus is rarely identified by molecular tests of the CSF in these patients, and it has been suggested that the mechanism for the complications may be a parainfectious cytokine storm. ${ }^{18}$

\section{Coronaviruses}

The severe CoV, severe acute respiratory syndrome (SARS) and MERS, have been associated with limited reports of both central and peripheral nervous system disease, including ADEM. ${ }^{19}$ Sporadic, seasonal $\mathrm{CoV}$ have also occasionally been implicated in neurological disease. ${ }^{20}$

COVID-19, caused by SARS-CoV-2, represents the most devastating respiratory pandemic since the influenza pandemics of 1918 ('Spanish flu'; H1N1), 1957 ('Asian flu'; H2N2) and 1968 ('Hong Kong flu'; H3N2). ${ }^{21}$ Reports of neurological syndromes associated with SARS-CoV2 are frequent, initially reported where the virus began in Wuhan, ${ }^{22}$ and continued in case reports and series from across the world. ${ }^{212324}$ A UK-wide surveillance study identified 153 cases with CNS disorders reflecting cerebrovascular events, altered mental status including 7 patients with encephalitis, and a surprising number of psychiatric syndromes, such as psychosis and catatonia. ${ }^{21}$

It is currently unclear how many cases are causally related to SARS-CoV-2 and in what proportion this is a coincidental infection. $^{23}$ It is becoming apparent that dysfunction of the clotting cascade, together with possible endotheliopathy, is in some cases associated with cerebrovascular disease in COVID-19. 212324 The number of patients with encephalopathy is also striking, and in a few cases the virus has been detected in CSF. ${ }^{21} 25$ Many cases of GBS and its variants are also emerging. ${ }^{26}$

\section{Conclusion}

The historical papers of von Economo, Horder and others are refreshing in their straightforward and detailed accounts of the symptoms, signs and clinical course of their patients, which risk being diminished in current studies if there is over-reliance on investigations alone.

The reporting of cases should be systematic and collaborative, which is far easier now, in the age of online platforms, than it was 100 years ago; such as is currently being employed through the UK-wide CoroNerve study (www.CoroNerve. 
com) and international collaborations, such as the COVID-19 NeuroNetwork (https://braininfectionsglobal.tghn.org/ covid-neuro-network/). In addition to analysis of clinical samples, these historic cases emphases the importance of histopathological descriptions, which may be more difficult to conduct now that postmortem material may be less frequently obtained. We are indebted to those who donate and their families, so that we, like von Economo and those before us, might better understand the impact of pandemic respiratory viruses on the CNS.

Perhaps the greatest lesson from our predecessors is to maintain clinical curiosity and a healthy degree of scepticism, to drive logical enquiry and experiment. Nevertheless, we are left with the original questions posed throughout this history: to what extent are these manifestations due to direct viral CNS infection, the host inflammatory response to non-CNS infection, or the broader psychosocial effects of pandemic infection, and who is at risk?

Despite the human and economic suffering of COVID-19, this pandemic represents the first time ever, for the neuroscience community to use the many tools at our disposal, including digital global collaboration and biobanking for next-generation and single-cell sequencing, 'omics, immunophenotyping, and genome-wide association, to finally begin to answer these questions.

Keep up to date with the latest developments in the neurological and psychiatric complications of COVID-19 via our JNNP blog: https://blogs.bmj.com/jnnp/ 2020/05/01/the-neurology-and-neuropsychiatry-of-covid-19/

\section{Twitter Benedict Daniel Michael @BenedictNeuro}

Funding The authors have not declared a specific grant for this research from any funding agency in the public, commercial or not-for-profit sectors.

Competing interests None declared.

Patient consent for publication Not required.

Provenance and peer review Commissioned; internally peer reviewed.
(2)

\section{OPEN ACCESS}

Open access This is an open access article distributed in accordance with the Creative Commons Attribution Non Commercial (CC BY-NC 4.0) license, which permits others to distribute, remix, adapt, build upon this work non-commercially, and license their derivative works on different terms, provided the original work is properly cited, appropriate credit is given, any changes made indicated, and the use is non-commercial. See: http://creativecommons.org/ licenses/by-nc/4.0/.

(c) Author(s) (or their employer(s)) 2020. Re-use permitted under CC BY-NC. No commercial re-use. See rights and permissions. Published by BMJ.

HVDT and MAE are joint first authors.

\section{(A) Check for updates}

To cite Van Den Tooren H, Ellul MA, Davies NWS, et al. J Neurol Neurosurg Psychiatry 2020;91:1129-1131.

Received 24 June 2020

Accepted 1 July 2020

Published Online First 21 September 2020

J Neurol Neurosurg Psychiatry 2020;91:1129-1131. doi:10.1136/jnnp-2020-324366

ORCID iD

Benedict Daniel Michael http://orcid.org/0000-00028693-8926

\section{REFERENCES}

1 Hoffman LA, Vilensky JA. Encephalitis lethargica: 100 years after the epidemic. Brain 2017;140:2246-51.

2 Vincent A. Encephalitis Lethargica. In: Turner MR, Kieran MC, eds. Landmark papers in neurology. Oxford University Press, 2015: 478-83.

3 Crookshank FG. A note on the history of epidemic encephalomyelitis. Bost Med Surg J 1920;182:34-45.

4 Reid AH, McCall S, Henry JM, et al. Experimenting on the past: the enigma of von Economo's encephalitis lethargica. J Neuropathol Exp Neurol 2001;60:663-70.

5 Tappe D, Alquezar-Planas DE. Medical and molecular perspectives into a forgotten epidemic: encephalitis lethargica, viruses, and high-throughput sequencing. I Clin Virol 2014:61:189-95.

6 Kaida K. Pathogenic roles of antiganglioside antibodies in immune-mediated neuropathies. Clin Exp Neuroimmunol 2013;4:60-9.

7 Salovin A, Glanzman J, Roslin K, et al. Anti-Nmda receptor encephalitis and nonencephalitic HSV-1 infection. Neurol Neuroimmunol Neuroinflamm 2018;5:e458.
8 Dale RC, Irani SR, Brilot F, et al. N-Methyl-D-Aspartate receptor antibodies in pediatric dyskinetic encephalitis lethargica. Ann Neurol 2009;66:704-9.

9 Bramwell E, Miller J. Encephalitis lethargica (epidemic encephalitis). The Lancet 1920;195:1152-8.

10 Watson GA. A case of encephalitis lethargica involving chiefly the cerebral cortex. J Neurol Psychopathol 1920;1:34-44.

11 Horder T. Epidemic encephalitis: Clinical papers by various authors. I Neurol Neurosurg Psychiatry 1920; $11-1: 221-35$

12 Coburn M. Short notes and clinical cases: report of a case of insomnia following encephalitis lethargica. J Neurol Psychopathol 1921;2:249-53.

13 Parkes Weber F, Shrubsall F, Cameron H, et al. Section for the study of disease in children: cases: hypertelorism. Proc R Soc Med 1928;21.

14 Young AW. A clinical analysis of an extrapyramidal syndrome; paralysis agitans and postencephalitic parkinsonism. J Neurol Neurosurg Psychiatry 1927;518:9-18.

15 Duvoisin RC, Lobo-Antunes J, Yahr MD. Response of patients with postencephalitic parkinsonism to levodopa. J Neurol Neurosurg Psychiatry 1972;35:487-95.

16 Surana P, Tang S, McDougall M, et al. Neurological complications of pandemic influenza A H1N1 2009 infection: European case series and review. Eur Pediatr 2011;170:1007-15.

17 Reed C, Chaves SS, Perez A, et al. Complications among adults hospitalized with influenza: a comparison of seasonal influenza and the $2009 \mathrm{H} 1 \mathrm{~N} 1$ pandemic. Clin Infect Dis 2014;59:166-74.

18 Goenka A, Michael BD, Ledger E, et al. Neurological manifestations of influenza infection in children and adults: results of a national British surveillance study. J Neurol Neurosurg Psychiatry 2014;58:775-84.

19 Ng Kee Kwong KC, Mehta PR, Shukla G, et al. COVID-19, SARS and MERS: a neurological perspective. J Clin Neurosci 2020;77:13-16.

20 Morfopoulou S, Brown JR, Davies EG, et al. Human coronavirus OC43 associated with fatal encephalitis. $N$ Eng/ J Med 2016;375:497-8.

21 Varatharaj A, Thomas N, Ma E, et al. UK-wide surveillance of neurological and neuropsychiatric complications of COVID-19 : The first 153 patients. Lancet Psychiatry 2020.

22 Mao L, Jin H, Wang M, et al. Neurologic manifestations of hospitalized patients with coronavirus disease 2019 in Wuhan, China. JAMA Neurol 2020;77:683-90.

23 Ellul M, Varatharaj A, Nicholson TR, et al. Defining causality in COVID-19 and neurological disorders. J Neurol Neurosurg Psychiatry 2020;91:811-2.

24 Beyrouti R, Adams ME, Benjamin L, et al. Characteristics of ischaemic stroke associated with COVID-19. J Neurol Neurosurg Psychiatry 2020:91:889-91.

25 Ellul M, Benjamin L, Singh B, et al. Neurological associations of COVID-19. SSRN Journal 2020.

26 Toscano G, Palmerini F, Ravaglia S, et al. Guillain-Barré syndrome associated with SARS-CoV-2. N Engl I Med 2020:382:2574-6. 